\title{
Indonesian Journal of Global Health Research
}

Volume 2 Number 4, November 2020, pp. 301 - 308

e-ISSN 2715-1972; p-ISSN 2714-9749

http://jurnal.globalhealthsciencegroup.com/index.php/IJGHR

\section{PREVENTIVE HEALTH BEHAVIORS OF COMMUNITY DURING COVID-19 PANDEMIC: A DESCRIPTIVE STUDY}

\author{
Ika Purnamasari*, Anisa Ell Raharyani \\ Universitas Sains Al Qur'an Wonosobo, Jl. Kyai Hasyim Asya ri No.Km, RW.03, Kalibeber, \\ Mojotengah, Kabupaten Wonosobo, Jawa Tengah, Indonesia 56351 \\ *ikapurnama@unsiq.ac.id
}

\begin{abstract}
The pandemic of coronavirus disease (COVID-19) has been declared by World Health Organization on March 11, 2020. COVID-19 is a disease caused by SARS-CoV-2. Some of preventive behaviors have been recommended to minimize the risk of COVID-19 infection in the general population, including staying-at-home orders, hand hygiene, prohibitions against mass gatherings, wearing a mask, and maintaining physical distance between persons. To describe community behaviors related to the implementation of the recommendation on covid-19 preventions. This research was a descriptive study involving 144 respondents as the community members of Wonosobo District, Indonesia. The data was analysed using descriptive analysis. The study showed that among the community involved, $95.8 \%$ of them were categorized as good, while the remaining $4.2 \%$ was categorized as enough. The category of good community behaviors was pointed out by the indication in which $77.8 \%$ of the community obeyed staying-at-home orders. As much as $56 \%$ of them still went shopping for groceries and $44.4 \%$ utilized both on-line shopping and delivery service facilities. Other good behaviors were indicated by $96.5 \%$ of the community were discipline in applying hand washing, 93.1\% of them kept the distance to others and avoided gatherings as well as $68.1 \%$ of the people kept wearing masks. The behaviour of the majority of the community were categorized as good. This condition is expected to support efforts to handle the COVID-19 cases to be carried out effectively.
\end{abstract}

Keywords: behaviors; community; covid-19; prevention

\begin{tabular}{|c|c|}
\hline $\begin{array}{l}\text { First Received } \\
18 \text { August } 2020\end{array}$ & $\begin{array}{c}\text { Accepted } \\
28 \text { September2020 }\end{array}$ \\
\hline $\begin{array}{c}\text { Final Proof Received } \\
08 \text { November } 2020\end{array}$ & $\begin{array}{c}\text { Published } \\
14 \text { November } 2020\end{array}$ \\
\hline $\begin{array}{l}\text { How to cite (in APA style) } \\
\text { Purnamasari, I., \& Raharyani, A. (2020). Preventive Health } \\
\text { Pandemic: A Descriptive Study. Indonesian Journal of } \\
\text { https://doi.org/10.37287/ijghr.v2i4.232 }\end{array}$ & $\begin{array}{l}\text { rs of Community During Covid-19 } \\
\text { Health Research, 2(4), 301-308. }\end{array}$ \\
\hline
\end{tabular}

\section{INTRODUCTION}

Recently, the world has been shocked by the corona virus which has attacked almost all countries including Indonesia. According to the Data until October $25^{\text {th }}$, 2020, the number of confirmed cases of covid-19 globally was reported as 45,512,186 cases from 216 infected countries and 180 countries with local transmission. In Southeast Asia, the number of confirmed cases was 8,924,840, of which $1.6 \%$ were questioned as dead. With the spread of covid19 cases in various countries, World Health Organization (WHO) has designated Covid-19 as a pandemic case. Indonesia is one of the countries with local transmission with a confirmed number of 400,483 cases and 13,612 thousand cases were reported died, which still increases every day. Covid-19 is an infectious disease caused by a coronavirus which is phylogenically included in the subgenus Sargecovirus, a single positive RNA virus type, and has a size of $120-160 \mathrm{~nm}^{3}$. This virus is now known as SARS Cov-2 (Severe Acute Respiratory Syndrome Coronavirus 2 ), and can cause symptoms ranging from mild to severe including shortness of breath. 
In general, the symptoms can include fever, cough, diarrhea (common cold), and pain in the body with an incubation period of 2-7 days (Wei Jei Guan, 2020).

Central Java is an area affected by Covid-19 with a total of 32,732 confirmed cases, of which 1711 cases died. Wonosobo District is one of the cities in Central Java with 1,453 confirmed cases, and 81 deaths on 28 October 2020. This number had continued to increase since the local government confirmed the first covid-19 case in Wonosobo in March 2020. The impact of the Covid-19 pandemic is felt by the community in limiting social activities. Therefore, it is necessary to take appropriate prevention and control efforts to minimize the spread of Covid-19. Various efforts have been conducted by the government to reduce the spread of the corona virus including large-scale social restrictions and adherence to health protocols. However, there was still an increased daily report in the number of confirmed cases along with the increased number of the death rate. In implementing health protocols, preventive efforts can be made by wearing masks, washing hands using soap, avoiding crowds or gathering and maintaining distance (Ministry of Health, 2020). This behavior is very important to be conducted by the community in an effort to break the chain of the spread of Covid-19. This study aimed to determine preventive behavior against covid-19 in the community of Wonosobo District.

\section{METHOD}

This study was a quantitative research with a survey method to describe people's behavior towards the prevention of Covid-19. The measuring instrument used was questionnaire related to COVID-19 preventive behavior by using Google Form application which was then distributed to the community in Wonosobo District via WhatsApp application. The questionnaire focused on people's behavior regarding Covid-19 prevention, including wearing masks, staying at home, washing hands, keeping distance and avoiding crowds or gathering, and utilizing online shops and delivery orders. A total of 144 samples were obtained randomly which then were processed. Data were taken in June 2020 to July 2020. Data processing was carried out by using frequency distribution. Before conducting the survey, respondents were asked to fill informed consent form to become a respondent which is distributed via Google Form.

\section{RESULTS}

The age of respondents ranged from 16 to 65 years old. Most of the respondents were between 26-35 years old (38.2\%), and only 2 respondents were between 56-65 years old $(1.4 \%)$. Based on their gender, there were 93 female and 51 male respondents. Their education levels also showed that most respondents had a diploma to bachelor's degree (71\%), while the respondents with junior high school education were 10 people, and 42 respondents had a high school education level/equivalent. Most of them had jobs as private sector employees (29.2\%), and the remaining are Civil Servants (15.3\%), Indonesian Army and Police (2.8\%), Housewives (18.75\%), entrepreneur (15.97\%), and others $(17.9 \%)$. Most of the results of community behavior related to the prevention of Covid-19 categorized as good by $95.8 \%$, while the remaining were categorized as moderate. 
Table 1.

Respondents' characteristics ( $\mathrm{n}=144)$

\begin{tabular}{llcc}
\hline \multicolumn{1}{c}{ Respondent characteristics } & \multicolumn{1}{c}{ Category } & $\mathrm{f}$ & $\%$ \\
\hline Age (years old) & $16-25$ & 17 & 11.8 \\
& $26-35$ & 55 & 38.2 \\
& $36-45$ & 51 & 35.4 \\
& $46-55$ & 19 & 13.2 \\
& $56-65$ & 2 & 1.4 \\
\hline Gender & Male & 51 & 35.4 \\
& Female & 93 & 64.6 \\
\hline Last Level of Education & Primary School & 1 & 0.7 \\
& Junior High School & 10 & 6.9 \\
& Senior High School & 42 & 29.2 \\
& Diploma-Bachelor & 71 & 49.3 \\
& Post Graduate & 20 & 13.9 \\
\hline Job & State Civil Apparatus & 22 & 15.3 \\
& Indonesian Army and Police & 4 & 2.8 \\
& Housewives & 27 & 18.75 \\
& Self-employed & 23 & 15.97 \\
& Private Employees & 42 & 29.2 \\
& Others & 26 & 17.9 \\
\hline
\end{tabular}

Table 2.

Preventive Behavior towards Covid-19(n=144)

\begin{tabular}{lcc}
\hline \multicolumn{1}{c}{ Preventive Behaviors } & $\mathrm{f}$ & $\%$ \\
\hline Stay at Home & 112 & 77.8 \\
Always & 31 & 21.5 \\
Sometimes & 1 & 0.7 \\
Never & 81 & 56.3 \\
\hline Leave home to shopping for groceries & 61 & 42.4 \\
Always & 2 & 1.3 \\
Sometimes & & \\
Never & 98 & 68.1 \\
Wearing Mask & 33 & 22.9 \\
Always & 13 & 9 \\
Sometimes & & \\
Never & 139 & 96.5 \\
\hline Hand washing with soap & 5 & 3.5 \\
Always & 0 & 0 \\
Sometimes & & \\
Never & 134 & 93.1 \\
\hline Physical and Avoid Gathering & 10 & 6.9 \\
Always & 0 & 0 \\
Sometimes & & \\
Never & 64 & 44.4 \\
\hline Utilize online shop and delivery order & 61 & 42.4 \\
Always & 19 & 13.2 \\
Sometimes & & \\
Never & 75 & 52.1 \\
\hline Take multivitamin & 54 & 37.5 \\
Always & 15 & 10.4 \\
Sometimes & & \\
Never & & \\
\hline & & \\
& & \\
\hline
\end{tabular}


Preventive behavior against covid-19 in the community of Wonosobo District is shown in table 2. The community's preventive behavior towards Covid-19 was shown by staying at home by $77.8 \%$ and people only leave home to buy groceries or foodstuffs by $56.3 \%$. People who wore masks when leaving the house were $68.1 \%$. Most of the people had carried out the health protocol according to the recommendations, which are by washing hands using soap or washing hands after touching objects by $96.5 \%$. In addition, as much as $93.1 \%$ of the community always kept their physical distance or avoid crowd or gathering. In this condition, only some people chose to shop only or used delivery orders by $44.4 \%$. They also took some multivitamin to keep their immunity.

\section{DISCUSSION}

This part of the paper discusses the preventive behavior against Covid-19 in the community of Wonosobo District. It was pointed out that people who always wash hands using soap were $96.5 \%$, while $93.1 \%$ of them always maintain physical distance and avoid crowds or gathering. According to Green, behavior is influenced by several dominant factors, such as predisposing factors (knowledge, belief), enabling factors (age, education level, socioeconomic), and enforcing factors (examples from community leaders).

\section{Wearing Mask}

The use of masks is highly recommended by WHO and is one of the efforts to prevent the corona virus. As it is known, covid-19 which is caused by SARS Co-V2, can spread through droplets. The use of masks is considered able to prevent the transmission of the virus from respiratory infections (Seongman, 2020). Masks that can be used by the public in general are cloth masks and surgical masks. For daily use, people are encouraged to wear cloth masks when traveling outside the house, such as riding a vehicle or for shopping. The results of this study prove that most people have used masks when going out and traveling. The use of cloth masks is not recommended for health but is very useful in reducing the risk of spreading infection due to viruses (Christiane, et al, 2020). According to a study, masks were effectively used to reduce transmission of viruses including SARS CoV-2, but the government must also provide knowledge to the public to make behavioral changes in self-protection measures by providing knowledge about microbiology, not just instructing what to do and what not to do (Ricky V Tso, 2020). WHO conveyed, in using a mask, there are several things that must be considered, including before taking a mask people should wash their hands using soap, the mask should cover mouth and nose, avoid holding the mask when it is in use, does not touch the front part of the mask when changing them and wear a fabric mask unless people in a particular risk group. This is especially important when they cannot stay physically distanced, particularly in crowded and poorly ventilated indoor settings. In addition, a medical or surgical mask must be worn by people over 60 years old, have underlying medical conditions, are feeling unwell, and during looking after an ill family member (WHO, 2020).

A study in Hong Kong stated that compliance with the use of masks will reduce the transmission of SARS Co-V2 compared to areas with low use of masks (Vincent, CC, et, al., 2020). This means that wearing masks in the community can contribute to control COVID-19, particularly, by controlling the spread of droplets from individuals with subclinical or mild COVID-19. 


\section{Hand Washing}

Washing hands is an activity that can be done independently to prevent the spread of covid-19 (Lotfinejad, 2020). Based on the Journal of Clinical Nursing, hands washing using soap and running water for about 20 seconds or using an alcohol-based hand sanitizer (if there is no water and soap) is the first step to stop the spread of infection (Mamdooh, 2020). Hand sanitizers are also available in various forms, and their formulations are effective at removing microorganisms on the hands, but they can also change the integrity of the skin. Alcohol-based hand sanitizer with moisturizer will minimize the sensitivity and the lowest irritation level compared to soap or other detergents (Chandler, et al. 2020). According to the CDC (Center for Disease Control and Prevention), there are several recommended times to wash your hands during this pandemic, including after touching public facilities that may also be touched by others, such as door handles, cashier desks, and so on, and before touching the eyes, nose, mouth (CDC, 2020).

In another study conducted in Banyumas community, it was found that the community's behavior towards preventing Covid was also high, including always washing hands, wearing masks, as well as keeping social distance (Endang T, 2020).

\section{Physical Distancing and Avoiding Crowds}

The transmission of SARS-CoV-2 is most strongly associated with close and prolonged contact in indoor environments. The highest risks of transmission are in crowded spaces over extended periods. Physical distancing is an important mitigation measure. Such situation means $2 \mathrm{~m}$ face-to-face distancing which if it cannot be achieved, then it is strongly recommended additional mitigation measures including (but not limited to) face coverings and minimizing duration of exposure are adopted (SAGE, 2020).

Keeping your distance and avoiding crowds or gathering is an important part of preventing the transmission of the corona virus. Maintaining a minimum distance of one meter or more from other people has been advised by WHO to minimize the risk of transmission from an infected person through coughing, sneezing or talking while inside buildings/indoor (WHO, 2020). Physical distance $<1 \mathrm{~m}$ is reported to result in a risk of transmission of $12.8 \%$, compared with $2.6 \%$ at a distance of $\geq 1 \mathrm{~m}$ (Jones NR, 2020). The UK Scientific Advisory Group for Emergencies (SAGE) also estimated that the risk of transmission of SARS-CoV-2 at a distance of $1 \mathrm{~m}$ could be 2-10 times higher at a distance of $2 \mathrm{~m}$, supporting the rule of physical distance of $1 \mathrm{~m}$ or more (SAGE, 2020). The results of other studies indicate that SARS-CoV-2 can spread beyond 1-2 $\mathrm{m}$ in concentrated packets through coughing or sneezing (Bourouiba L, 2016). Other recent virus outbreaks, such as SARS-CoV-1, MERS-CoV, and avian flu, have various studies reporting suspected spread of more than $2 \mathrm{~m}$ (Yu ITS et.al, 2020). This research evidence corroborates recommendations for avoiding crowds or gathering and maintaining physical distance, including suggestions for stay at home.

The size of the droplets is also considered to have an effect on virus transmission, especially in relation to the distance of the droplets fall. Droplet size is divided into 2; large and small. The large size emitted into the air will fall faster and can be at a distance of 1-2 meters, while small droplets/aerosols cannot move without air flow, these droplets will fall not far from the exhaler (Wells WF in Jones NR, 2020).

The rules for safe physical distancing are based on evolving science. The distribution of 
virus particles is influenced by many factors, including airflow, droplet size, factors that affect risk, including ventilation, occupancy and time of exposure. This rule of keeping distance will be effective by considering these influencing factors. Research evidence shows that SARS-CoV-2 can travel more than $2 \mathrm{~m}$ through activities such as coughing and shouting (Jones NR, 2020).

Thus, the preventive behavior of Covid-19 transmission recommended by the government and also WHO is a unit of action that complements one another. This behavior will be meaningful if it is implemented with a combined strategy of using masks, washing hands, maintaining distance and avoiding crowds or gathering.

\section{CONCLUSION}

The results of this study concluded that people in Wonosobo District have good behavior towards preventing Covid-19, shown by staying at home, using masks, always washing hands using soap, keeping distance and avoiding crowds, as well as consuming multivitamins. There should be a further research to determine the relationship between other behavioral factors such as demography and knowledge.

\section{ACKNOWLEDGEMENTS}

Thank you to the Faculty of Health Sciences University of Sains Al Qur'an Wonosobo who has provided material support for the implementation of research and publication of this scientific article.

\section{REFERENCES}

Bourouiba L. (2016). Images in clinical medicine. A sneeze. New England Journal of Medicine. 2016;375:e15.doi:10.1056/NEJMicm1501197.pmid:27557321

Center of Disease Control (CDC). (2020). When and How to Wash Your Hands. Retrieved from https://www.cdc.gov/handwashing/when-how-handwashing.html.

Chandler W, et al. (2020). Hand hygiene during COVID-19:Recommendations from the American Contact Dermatitis Society. Journal of The American Academy of dermatology. Articlel in Press. https://www.sciencedirect.com/science/article/pii/S0190962220322568

Christiane Matuschek, et al,. (2020). Face masks: benefits and risks during the COVID19 crisis. Europian Journal of Medical Research. Vol.25: 32. 2020 doi: $10.1186 / \mathrm{s} 40001-020-00430-5$

Dinas Kesehatan Kabupaten Wonosobo. (2020). https://corona.wonosobokab.go.id/

Endang T, Lita Heni K. (2020). An Analisys of People's Behavioral Changes To prevent covid-19 Transmission Based on Integrated Behavior Model. Jurnal Keperawatan Soedirman. $15 \quad$ (2). 2020:66-73. $\quad$ DOI: 10.20884 /jks.2020.15.2.1441

Handayani, P. (2019). Penyakit Virus Corona 2019. Jurnal Respiratori Indo. Vol.40 No. 2. April 2020 
Jones Nicholas R, Qureshi Zeshan U, Temple Robert J, Larwood Jessica PJ, Greenhalgh Trisha, Bourouiba Lydia et al. (2000). Two metres or one: what is the evidence for physical distancing in covid-19?. BMJ 370. m3223

Kementrian Kesehatan RI. (2020). https://www.kemkes.go.id/resources/download/infoterkini/COVID-19/TENTANG\%20NOVEL\%20CORONAVIRUS.pdf. Retrieved from https://www.kompas.com/covid-19

Mamdooh, A., Debra Jackson Ao., Helen Aveyard., Joanne Brooke. (2020). COVID-19 reinforces the importance of handwashing. Jurnal of Clinical Nursing . 2020;00:12. DOI: $10.1111 /$ jocn. 15313

N Lotfinejad, A Peters, D Pitlet,. (2020). Hand Hygiene and the Novel Coronavirus Pandemic : The role of healthcare workers. The Journal of Hospital Infection. Vol. 105, Issue 4, p 776-777.https://doi.org/10.1016/j.jhin.2020.03.017

Notoadmojo S. (1993). Pengantar Pendidikan Kesehatan dan Ilmu Perilaku Kesehatan. PT Andi Offset. Yogyakarta.

Ricky, V. T., Benjamin, J. C., (2020). Importance of Face Masks for Covid-19: A Call for Effectice Public Education. Clinical Infectious Diseases. ciaa593, https://doi.org/10.1093/cid/ciaa593

Scientific Advisory Group on Emergencies (SAGE). (2020). Transmission of SARS$\mathrm{CoV}-2$ and mitigating measures. https://assets.publishing.service.gov.uk/government/uploads/system/upl oads/attachment_data/file/892043/S0484_Transmission_of_SARS-CoV2_and_Mitigating_Measures.pdf

Seongman Bae, MD., et al. (2020). Effectiveness of Surgical and Cotton Masks in Blocking SARS-CoV-2: A Controlled Comparison in 4 Patients. Annals of Internal Medicine. Retrieved from https://www.acpjournals.org/doi/10.7326/M20$\underline{1342}$

Vincent Chi Chung C., et al., (2020). The role of community-wide wearing of face mask for control of coronavirus disease 2019 (COVID-19) epidemic due to SARS-CoV2. Journal Infection. $2020 \mathrm{Jul}$; 81(1): 107-114. doi: 10.1016/j.jinf.2020.04.024

Wei Jie G, et al. (2020). Clinical Characteristics of Coronavirus Disease 2019 in China. New England Journal of Medicine. 2020; 382:1708 - 1720. DOI: 10.1056/NEJMoa2002032

World Health Organization (WHO). (2020). Media Statement: The role and Need of Masks during covid-19 outbreak. Media release 2020 March 6. Retrieved from https://www.who.int/indonesia/news/detail/06-03-2020-media-statement-the-roleand-need-of-masks-during-covid-19-outbreak

World Health Organization (WHO). (2020). Corona Virus (Covid-19) outbreak, Retrieved from https://www.who.int/emergencies/diseases/novel-coronavirus2019/advice-for-public 
World Health Organization (WHO). (2020). Corona Virus (Covid-19) outbreak, https://www.who.int/emergencies/diseases/novel-coronavirus-2019

Yu ITS, Li Y, Wong TW, et al. (2004). Evidence of airborne transmission of the severe acute respiratory syndrome virus. New England Journal of Medicine. 2004; ;350:1731-9. doi:10.1056/NEJMoa032867. pmid:15102999 